\title{
The effect of dry period length and postpartum level of concentrate on milk production, energy balance, and plasma metabolites of dairy cows across the dry period and in early lactation
}

\author{
R. J. van Hoeij,, ${ }^{\star 1}$ J. Dijkstra,† R. M. Bruckmaier,ł J. J. Gross,ł T. J. G. M. Lam,§\# G. J. Remmelink,II \\ B. Kemp, ${ }^{*}$ and A. T. M. van Knegsel* \\ *Adaptation Physiology Group, and \\ †Animal Nutrition Group, Department of Animal Sciences, Wageningen University and Research, PO Box 338, $6700 \mathrm{AH}$, \\ Wageningen, the Netherlands \\ ¥Veterinary Physiology, Vetsuisse Faculty, University of Bern, Bremgartenstrasse 109a, CH-3001 Bern, Switzerland \\ $\S$ Department of Farm Animal Health, Utrecht University, PO Box 80151, 3508 TD, Utrecht, the Netherlands \\ \#GD Animal Health, PO Box 9, 7400 AA, Deventer, the Netherlands \\ IILivestock Research, Wageningen University and Research, PO Box 338, 6700 AH, Wageningen, the Netherlands
}

\begin{abstract}
Shortening or omitting the dry period (DP) improves energy balance (EB) in early lactation because of a reduction in milk yield. Lower milk yield results in lower energy demands and requires less energy intake. The aim of this study was to evaluate the effects of DP length and concentrate level postpartum on milk yield, feed intake, EB, and plasma metabolites between wk -4 and 7 relative to calving of cows of second parity or higher. Holstein-Friesian dairy cows $(\mathrm{n}=123)$ were assigned randomly to 1 of 2 DP lengths: 0 -d DP ( $\mathrm{n}=$ $81)$ or $30-d$ DP $(n=42)$. Prepartum, cows with a $0-d$ $\mathrm{DP}$ received a lactation ration based on grass silage and corn silage (6.4 MJ of net energy for lactation $/ \mathrm{kg}$ of dry matter). Cows with a 30-d DP received a dry cow ration based on grass silage, corn silage, and straw (5.4 MJ of net energy for lactation/kg of dry matter). Postpartum, all cows received the same basal lactation ration as provided to lactating cows prepartum. Cows with a 0 -d DP were fed a low level of concentrate up to $6.7 \mathrm{~kg} / \mathrm{d}$ based on the requirement for their expected milk yield (0-d DP-L; $\mathrm{n}=40)$ or the standard level of concentrate up to $8.5 \mathrm{~kg} / \mathrm{d}$ (0-d DP-S; $\mathrm{n}=41)$, which was equal to the concentrate level for cows with a $30-d$ DP (30-d DP-S; $n=42$ ) based on requirements for their expected milk yield. Prepartum dry matter intake, concentrate intake, basal ration intake, energy intake, plasma $\beta$-hydroxybutyrate (BHB), and insulin concentrations were greater and plasma free fatty acids (FFA) and glucose concentrations were lower, but EB was not different in cows with a 0-d DP compared with cows
\end{abstract}

Received July 6, 2016.

Accepted February 25, 2017.

${ }^{1}$ Corresponding author: renny.vanhoeij@wur.nl with a 30-d DP. During wk 1 to 3 postpartum, milk fat yield and plasma BHB concentration were lower and dry matter intake and concentrate intake were greater in cows with a $0-d$ DP compared with cows with a $30-d$ DP. During wk 4 to 7 postpartum, fat- and proteincorrected milk (FPCM), lactose content, and lactose and fat yield were lower in 0-d DP-L or 0-d DP-S cows compared with 30-d DP-S cows. Basal ration intake, EB, body weight, plasma glucose, and insulin and insulin-like growth factor-1 concentrations were greater and plasma FFA and BHB concentrations were lower in 0-d DP-L and 0-d DP-S cows compared with 30-d DP-S cows. Concentrate and energy intake were lower in 0-d DP-L cows than in 0-d DP-S or 30-d DP-S cows. Milk yield and concentrations of plasma metabolites did not differ in wk 4 to 7 , although EB was lower in wk 6 and 7 postpartum in 0-d DP-L cows than in 0-d DP-S cows. In conclusion, a 0-d DP reduced milk yield and improved EB and metabolic status of cows in early lactation compared with a 30-d DP. Reducing the postpartum level of concentrate of cows with a 0-d DP did not affect fat- and protein-corrected milk yield or plasma FFA and BHB concentrations in early lactation but did reduce EB in wk 6 and 7 postpartum.

Key words: continuous milking, metabolic status, parity, dietary energy level

\section{INTRODUCTION}

A shortened or omitted dry period (DP) improves energy balance (EB) in early lactation compared with a conventional DP (Rastani et al., 2005; Van Knegsel et al., 2014). Moreover, the incidence of ketosis tends to be lower in cows with a shortened or omitted DP compared with cows with a conventional DP (Santschi et al., 2011; Van Knegsel et al., 2013). Energy balance and 
health status are affected by DP length, and plasma metabolite concentrations differ among cows with different DP lengths. Postpartum, cows with an omitted DP have a greater plasma glucose concentration and lower plasma free fatty acids (FFA) and BHB concentrations than cows with a conventional DP (Andersen et al., 2005; de Feu et al., 2009; Bernier-Dodier et al., 2010).

The improvement of EB after an omitted DP was mostly attributable to a reduction in milk yield in the first $10 \mathrm{wk}$ (Rastani et al., 2005), 12 wk (de Feu et al., 2009), or 14 wk (Van Knegsel et al., 2014) of the subsequent lactation. More specifically, an omitted DP resulted in an 11\% (Rastani et al., 2005), 12\% (Van Knegsel et al., 2014), or 16\% (de Feu et al., 2009) lower milk yield compared with cows with a shortened DP. Additionally, compared with a short DP, omitting the DP resulted in a larger reduction in milk yield in the subsequent lactation in cows in parity 2 compared with cows in parity $\geq 3$ (Annen et al., 2004; Van Knegsel et al., 2014). Lower milk yield results in lower energy demands and potentially requires less energy intake. To our knowledge, in all experimental studies that compared cows with different DP lengths, the same energy level was offered to cows in all experimental groups during lactation, and energy level was not adjusted to the lower expected milk yield after a short or omitted DP. Moreover, the lower milk yield of cows with a 0-d DP was related to an increase in BCS in mid and late lactation (Chen et al., 2016). It is unclear whether feeding less energy to cows with a 0-d DP, according to their requirement for expected milk yield, results in an even lower milk yield, a decreased EB, or both. Performance of cows with a $0-d$ DP and a low energy level is relevant compared with both cows with a DP and an energy level for their expected milk yield and cows with a 0-d DP and the same energy level as cows with a DP. In several earlier studies, a reduction of concentrate level was related to a lower total DMI, energy intake, milk yield, EB, and a greater plasma BHB concentration in early lactation, although cows may increase roughage intake to compensate for a lower concentrate intake (Reist et al., 2003; Kokkonen et al., 2004; Dieho et al., 2016). According to Reist et al. (2003), a lower concentrate level also resulted in lower plasma glucose, insulin, IGF-1, and greater FFA concentration, whereas in Kokkonen et al. (2004) FFA and insulin were not affected by a lower concentrate level. Additionally, no parity effect was observed for plasma IGF-1 and BHB concentration, but the plasma insulin concentration was greater and the plasma FFA concentration was lower in multiparous cows than in primiparous cows (Meikle et al., 2004). Cows in these studies most likely had a conventional DP length of approximately $60 \mathrm{~d}$. It is unclear whether differences exist in plasma metabolite concentrations among parities being fed a lower concentrate level following a 0-d DP. If EB is not negatively affected, a lower energy intake of cows with a 0 -d DP is of interest because it might reduce feed costs, may reduce the risk of overconditioning of cows with a 0-d DP, and is potentially beneficial for net herd returns as well as cow health and welfare. The aim of this study was to evaluate the effects of DP length and postpartum concentrate level on milk yield and composition, feed intake, EB, and plasma metabolites between wh -4 and 7 relative to calving of cows of second parity or higher.

\section{MATERIALS AND METHODS}

\section{Animals, Housing, and Experimental Design}

The Institutional Animal Care and Use Committee of Wageningen University (the Netherlands) approved the experimental protocol in compliance with the Dutch law on animal experimentation (protocol no. 2014125). The experiment was conducted at the Dairy Campus research herd (Lelystad, the Netherlands) between January 27, 2014, and August 26, 2015. The research herd comprised 400 lactating Holstein cows. Cows were selected based on (1) being bred with a Holstein sire, (2) an expected calving interval of $<490 \mathrm{~d}$, (3) a daily milk yield of $>16 \mathrm{~kg}$ at $90 \mathrm{~d}$ before the expected calving date, and 4) no clinical mastitis or high SCC (>250,000 cells $/ \mathrm{mL}$ ) at the final 2 test days before drying off. In total, 141 cows entered the experiment, including 6 cows that entered twice. A total of 18 cows were excluded because of various reasons, including Johne's disease $(n=1)$, a broken hip $(n=1)$, severe clinical leg or claw problems $(n=2)$, severe clinical mastitis $(\mathrm{n}=2)$, acute death $(\mathrm{n}=3)$, incorrect ration composition $(\mathrm{n}=5)$, or an unplanned DP for cows assigned to a 0 -d DP $(\mathrm{n}=4)$. The final data set consisted of 123 cows (58 with postpartum parity 2 and 65 with postpartum parity $\geq 3$ ). To obtain a balanced distribution of cows across treatments, groups were made of 3 cows with similar expected calving date, milk yield in the previous lactation, and parity $(2, \geq 3)$ in the subsequent lactation. Within groups, cows were assigned randomly to a DP length of $0 \mathrm{~d}(2 / 3)$ or $30 \mathrm{~d}(1 / 3)$. Within the group of cows with a $0-d$ DP, cows were assigned randomly to either a low level of concentrate based on the requirement for their expected milk yield or a standard level of concentrate based on the requirement for the expected milk yield of cows with a 30-d DP. This resulted in the following 3 treatments: cows 
with a 30-d DP fed the standard level of concentrate required for their expected milk yield (30-d DP-S; $\mathrm{n}=42)$, cows with a 0 -d DP fed the same standard concentrate level as cows with a 30-d DP (0-d DP-S; $\mathrm{n}=41$ ), and cows with a $0-\mathrm{d}$ DP fed a low concentrate level $(\mathbf{0}-\mathbf{d} \mathbf{D P}-\mathbf{L} ; \mathrm{n}=40)$. The low level of concentrate was calculated based on the expected milk yield of cows with a $0-d$ DP. This calculation was based on previous research showing that cows with a 0 -d DP produced $12 \%$ less fat- and protein-corrected milk (FPCM) compared with cows with a 30-d DP (35.4 and $40.4 \mathrm{~kg}$ of FPCM/d, respectively; Van Knegsel et al., 2014). The experiment started $4 \mathrm{wk}$ prepartum and lasted until 7 wk postpartum. Cows were housed in a freestall with a slatted floor and cubicles. Cows were milked twice daily at approximately 0600 and $1800 \mathrm{~h}$. Disease incidence and treatment were recorded daily. Treated cows were kept in the experiment.

The drying off protocol for cows with a 30-d DP consisted of a transition to the dry cow ration at $\mathrm{d} 7$ before drying off and transition to milking once daily at $\mathrm{d} 4$ before drying off. At drying off, no dry cow antibiotics were used.

\section{Rations}

Prepartum, cows with a 0-d DP received a lactation ration that consisted of grass silage, corn silage, soybean meal, sugar beet pulp, wheat straw, urea, and vitamins and minerals (6.4 MJ of NE/ $\mathrm{kg}$ of DM; Table $1)$. Lactating cows received $1 \mathrm{~kg} / \mathrm{d}$ of standard concentrate in the milking parlor (Table 2). Cows with a 30-d DP received a dry cow ration that consisted of grass silage, corn silage, wheat straw, rapeseed meal, urea, and vitamins and minerals (5.4 MJ of $\mathrm{NE} / \mathrm{kg}$ of $\mathrm{DM}$ ).

Postpartum, all cows received the same lactation basal ration up to 49 DIM as provided to the prepartum lactating cows, including $1 \mathrm{~kg} / \mathrm{d}$ of standard concentrate in the milking parlor. All cows received the experimental concentrate at a level of $1 \mathrm{~kg} / \mathrm{d}$ from on average $10 \mathrm{~d}$ before the expected calving date (Table 2 ). The experimental concentrate increased stepwise by $0.3 \mathrm{~kg} / \mathrm{d}$ from 4 DIM up to $8.5 \mathrm{~kg} / \mathrm{d}$ at 28 DIM for cows receiving the standard concentrate level (30-d DP-S and 0-d DP-S) or stepwise by $0.3 \mathrm{~kg} / \mathrm{d}$ from 4 DIM up to $6.7 \mathrm{~kg} / \mathrm{d}$ at 22 DIM for cows receiving the low concentrate level (0-d DP-L). Rations were optimized aiming at a difference of $12 \%$ net energy intake through the basal ration and concentrate. Experimental concentrate was provided individually over 6 periods within $24 \mathrm{~h}$ by a computerized feeder located in the freestall that was available to all cows at all times (Manus VC5, DeLaval, Steenwijk, the Netherlands). Concentrate was supplied
Table 1. Ingredient and nutrient composition of the average dry cow ration and the lactation ration

\begin{tabular}{|c|c|c|}
\hline Item & $\begin{array}{l}\text { Dry cow } \\
\text { ration }\end{array}$ & $\begin{array}{l}\text { Lactation } \\
\text { ration }\end{array}$ \\
\hline \multicolumn{3}{|l|}{ Ingredient ( $\mathrm{g} / \mathrm{kg}$ of $\mathrm{DM})$} \\
\hline Grass silage & 473 & 437 \\
\hline Corn silage $^{2}$ & 181 & 338 \\
\hline Sugar beet pulp & - & 97 \\
\hline Rapeseed meal & 81 & - \\
\hline Soybean meal (high rumen bypass) ${ }^{3}$ & - & 84 \\
\hline Wheat straw & 243 & 20 \\
\hline Urea $^{4}$ & 7.2 & 3.7 \\
\hline Vitamins and minerals ${ }^{5}$ & 14 & 20 \\
\hline \multicolumn{3}{|l|}{ Nutrient composition $(\mathrm{g} / \mathrm{kg}$ of $\mathrm{DM})$} \\
\hline $\mathrm{DM}(\mathrm{g} / \mathrm{kg}$ of product) & 547 & 418 \\
\hline Ash & 88 & 82 \\
\hline $\mathrm{CP}$ & 114 & 137 \\
\hline Crude fat & 32 & 33 \\
\hline NDF & 528 & 419 \\
\hline $\mathrm{ADF}$ & 316 & 237 \\
\hline ADL & 35 & 20 \\
\hline Starch & 70 & 124 \\
\hline Sugar & 63 & 62 \\
\hline $\mathrm{IDP}^{6}$ & 53 & 79 \\
\hline RDP balance $^{7}$ & 8.1 & 7.8 \\
\hline $\mathrm{NE}^{8}(\mathrm{MJ} / \mathrm{kg}$ of $\mathrm{DM})$ & 5.4 & 6.4 \\
\hline
\end{tabular}

${ }^{1}$ Chemical composition of grass silage $(\mathrm{g} / \mathrm{kg}$ of DM): DM, $407 \mathrm{~g} / \mathrm{kg}$ of product; crude ash, 115; CP, 132; crude fat, 42; NDF, 484; ADF, 281; ADL, 19; sugar, 113; IDP, 66; RDP balance, 1.8; NE, $6.2 \mathrm{MJ} /$ $\mathrm{kg}$ of DM.

${ }^{2}$ Chemical composition of corn silage $(\mathrm{g} / \mathrm{kg}$ of DM): DM, $361 \mathrm{~g} / \mathrm{kg}$ of product; crude ash, 51; CP, 65; crude fat, 31; NDF, 384; ADF, 220; ADL, 18; starch, 352; sugar, 3.7; IDP, 48; RDP balance, 36; NE, 6.8 $\mathrm{MJ} / \mathrm{kg}$ of DM.

${ }^{3}$ Soybean meal was treated with formaldehyde.

${ }^{4}$ Urea was fed in the dry cow ration between April 2015 and August 2015. Urea was added to the dry cow ration when CP content was lower than $150 \mathrm{~g} / \mathrm{kg}$ of DM or RDP balance was lower than 0 .

${ }^{5}$ The composition of minerals and vitamins for the dry cow ration was as follows: Ca, $20 \mathrm{~g} / \mathrm{kg} ; \mathrm{P}, 30 \mathrm{~g} / \mathrm{kg} ; \mathrm{Na}, 34 \mathrm{~g} / \mathrm{kg} ; \mathrm{Cl}, 59 \mathrm{~g} / \mathrm{kg} ; \mathrm{Mg}, 250$ $\mathrm{g} / \mathrm{kg}$; I, $100 \mathrm{mg} / \mathrm{kg}$; Cu, 2,200 mg/kg; Mn, 3,000 mg/kg; total S, $25 \mathrm{~g} /$ $\mathrm{kg} ; \mathrm{Zn}, 3,300 \mathrm{mg} / \mathrm{kg}$; Se, $35 \mathrm{mg} / \mathrm{kg}$; Co, $35 \mathrm{mg} / \mathrm{kg}$; vitamin A, 400,000 IU; vitamin $\mathrm{D}_{3}, 125,000 \mathrm{IU}$; vitamin $\mathrm{E}, 10,000 \mathrm{IU}$. The composition of minerals and vitamins for the lactation ration was as follows: Ca, 155 $\mathrm{g} / \mathrm{kg} ; \mathrm{P}, 0 \mathrm{~g} / \mathrm{kg} ; \mathrm{Na}, 75 \mathrm{~g} / \mathrm{kg} ; \mathrm{Cl}, 116 \mathrm{~g} / \mathrm{kg} ; \mathrm{Mg}, 120 \mathrm{~g} / \mathrm{kg} ;$ total S, 40 $\mathrm{g} / \mathrm{kg} ; \mathrm{I}, 100 \mathrm{mg} / \mathrm{kg} ; \mathrm{Cu}, 1,600 \mathrm{mg} / \mathrm{kg} ; \mathrm{Mn}, 1,500 \mathrm{mg} / \mathrm{kg} ; \mathrm{Zn}, 1,500 \mathrm{mg} /$ $\mathrm{kg}$; Se, $34 \mathrm{mg} / \mathrm{kg}$; Co, $45 \mathrm{mg} / \mathrm{kg}$; vitamin A, 500,000 IU; vitamin $\mathrm{D}_{3}$, 65,000 IU; vitamin E, 5,000 IU.

${ }^{6} \mathrm{IDP}=$ intestinal digestible protein; calculated according to the Dutch protein evaluation system (Tamminga et al., 1994).

${ }^{7}$ Calculated according to the Dutch protein evaluation system (Tamminga et al., 1994).

${ }^{8}$ Calculated according to the Dutch NE system for lactation (Van Es, 1975). Values for NE, IDP, and RDP balance of grass silage, corn silage, and sugar beet pulp were based on near-infrared spectrometry (Blgg AgroXpertus, Wageningen, the Netherlands). Values for IDP, RDP balance, and NE of rapeseed meal and soybean meal were obtained from the manufacturer (Agrifirm, Apeldoorn, the Netherlands). Values for wheat straw and urea were obtained from Centraal Veevoeder Bureau feed tables (CVB, 2011).

separately from the basal ration. Cows had free access to water and the basal ration (dry cow or lactation) throughout the experiment. Rations were mixed once daily at approximately $1000 \mathrm{~h}$ and fed twice daily at 
Table 2. Ingredient and nutrient composition of the standard and experimental concentrates

\begin{tabular}{|c|c|c|}
\hline Item & Standard & Experimental \\
\hline \multicolumn{3}{|l|}{ Ingredient $(\mathrm{g} / \mathrm{kg})$} \\
\hline Palm kernel, expeller & 148 & 197 \\
\hline Corn & 241 & 48 \\
\hline Lupine & & 2.9 \\
\hline Sugar beet pulp (maximum $12 \%$ sugar) & 23 & \\
\hline Citrus pulp & 157 & 132 \\
\hline Wheat & 46 & 141 \\
\hline Wheat meal & & 1 \\
\hline Soybean hulls & & 186 \\
\hline Soybean meal & 32 & 3.0 \\
\hline Soybean meal (high rumen bypass) & 14 & 60 \\
\hline Rapeseed meal & 94 & 50 \\
\hline Rapeseed meal (high rumen bypass) & 87 & 77 \\
\hline Molasses, cane & 29 & 39 \\
\hline Molasses, beet & 12 & \\
\hline Protamylasse $^{1}$ & 35 & \\
\hline Beet vinasse $^{2}$ & 51 & \\
\hline Citrocol $^{3}$ & 11 & 39 \\
\hline Linseed oil & & 2.0 \\
\hline Palm oil & 2.6 & 3.9 \\
\hline Calcium carbonate & 2.5 & 2.3 \\
\hline Sodium chloride & 4.5 & 4.8 \\
\hline Magnesium oxide & 4.4 & 4.5 \\
\hline Urea & 4.5 & 3.0 \\
\hline Vitamin E & 0.8 & 1.0 \\
\hline Selenium & 1.8 & 2.0 \\
\hline Methionine source $^{4}$ & 0.5 & 0.6 \\
\hline \multicolumn{3}{|l|}{ Nutrient composition $(\mathrm{g} / \mathrm{kg})$} \\
\hline $\mathrm{DM}(\mathrm{g} / \mathrm{kg}$ of product) & 887 & 869 \\
\hline $\mathrm{CP}$ & 173 & 173 \\
\hline Ash & 56 & 58 \\
\hline Crude fat & 42 & 41 \\
\hline NDF & 255 & 337 \\
\hline $\mathrm{ADF}$ & 139 & 205 \\
\hline $\mathrm{ADL}$ & 41 & 43 \\
\hline Starch & 208 & 118 \\
\hline Sugar & 76 & 78 \\
\hline $\mathrm{IDP}^{5}$ & 119 & 123 \\
\hline RDP balance $^{6}$ & 22 & 16 \\
\hline $\mathrm{NE}^{7}(\mathrm{MJ} / \mathrm{kg}$ of $\mathrm{DM})$ & 7.7 & 7.4 \\
\hline
\end{tabular}

${ }^{1}$ Potato juice concentrate (Avebe, Veendam, the Netherlands). Chemical composition of protamylasse ( $\mathrm{g} / \mathrm{kg}$ of DM): DM, $548 \mathrm{~g} / \mathrm{kg}$ of product; crude ash, 290; sugar, 57; CP, 327; IDP, 52; RDP balance, 228; NE, 6.2 MJ/kg of DM.

${ }^{2}$ Chemical composition of beet vinasse ( $\mathrm{g} / \mathrm{kg}$ of product): DM, 663 ; crude ash, 174; CP, 214; sugar, 37; NDF, 2; ADF, 1; IDP, 34; RDP balance, 148; NE, $4.1 \mathrm{MJ} / \mathrm{kg}$ of DM.

${ }^{3}$ Used as a binding agent in the rations (Citrique Belge, Tienen, Belgium)

${ }^{4}$ Methionine as 2-hydroxy-4-methylthiobutanoic acid isopropyl ester (MetaSmart Dry, Adisseo, Antony, France).

${ }^{5} \mathrm{IDP}=$ intestinal digestible protein; calculated according to the Dutch protein evaluation system (Tamminga et al., 1994).

${ }^{6}$ Calculated according to the Dutch protein evaluation system (Tamminga et al., 1994).

${ }^{7}$ Calculated according to the Dutch NE system for lactation (Van Es, 1975). Values for IDP, RDP balance, and NE were obtained from the manufacturer (Agrifirm, Apeldoorn, the Netherlands).

approximately 1000 and $1700 \mathrm{~h}$. The DM content of basal rations was measured daily. Forage samples were taken weekly and stored at $-20^{\circ} \mathrm{C}$ until analysis. For- age samples were pooled per batch (average $=8 \mathrm{wk}$; each batch of silage was harvested on the same day) for analysis of DM content, NE, intestinal digestible protein (IDP), and RDP balance (RDPB; near-infrared spectrometry; Eurofins Agro Laboratories, Wageningen, the Netherlands). Net energy was calculated using the Dutch NE system for lactation (VEM), and IDP and RDPB were calculated according to the Dutch protein evaluation system (Tamminga et al., 1994) based on near-infrared spectrometry values. Concentrate composition was available per batch (each batch covering 2-3 wk) and was used to calculate NE, IDP, and RDPB per batch $($ median $=3 \mathrm{wk})$. Values for NE, IDP, and RDPB per batch of concentrate, rapeseed meal, and soybean meal were obtained from the manufacturer (Agrifirm, Apeldoorn, the Netherlands). Values for NE, IDP, and RDPB of wheat straw and urea were obtained from Centraal Veevoeder Bureau feed tables (CVB, 2011). Forage and concentrate samples were pooled per 6-mo period for analysis of DM (EC, 2009, part III A), CP (Kjeldahl; EC, 2009, part III C), crude fat (EC, 2009, part III H method A), NDF (ISO, 2006; 16472), ADF and ADL (ISO, 2008; 13906), starch (enzymatic; ISO, 2004; 15914), sugar (glucose; EEC, 1972), and crude ash (EC, 2009, part III M). Masterlab (Boxmeer, the Netherlands) conducted all analyses according to the listed ISO references and EC regulations.

\section{Measurements}

Milk Yield and Milk Composition. Milk yield was recorded daily from 4 wk prepartum until 7 wk postpartum. Milk samples for fat, protein, and lactose analysis (ISO 9622, 2013; Qlip, Zutphen, the Netherlands) were collected 4 times/wk (Tuesday afternoon, Wednesday morning, Wednesday afternoon, and Thursday morning) and were analyzed as a pooled sample per cow per week. Fat- and protein-corrected milk was calculated as follows (CVB, 2011):

$$
\begin{aligned}
\mathrm{FPCM} & =(0.337+0.116 \times \text { fat content }+0.06 \\
& \times \text { protein content }) \times \text { milk yield }
\end{aligned}
$$

Feed Intake, $B W, B C S$, and $E B$. Basal ration was provided and daily intake was measured individually using roughage intake control troughs (Insentec, Marknesse, the Netherlands). The stocking density was 2 cows per trough. The actual quantity of concentrate dispensed $(\mathrm{kg} / \mathrm{d})$ was recorded. Body weight was recorded daily before each milking. Dry cows were weighed once per week. Body condition was scored every 4 wk by the same person using a 1 -to- 5 scale (Ferguson et al., 1994). 
Energy balance was calculated per week according to the Dutch VEM system (Van Es, 1975) as the difference between intake of VEM and the requirements of VEM for maintenance, milk yield, and pregnancy $(1,000 \mathrm{VEM}=6.9 \mathrm{MJ}$ of NE). According to the VEM system, the daily requirement for maintenance is 42.4 $\mathrm{VEM} / \mathrm{kg}^{0.75}$ of BW, the requirement for milk yield is $442 \mathrm{VEM} / \mathrm{kg}$ of FPCM, and the daily requirement for pregnancy is 2700 VEM in the last $4 \mathrm{wk}$ prepartum. Energy intake and $\mathrm{EB}$ are expressed in $\mathrm{kJ} / \mathrm{kg}^{0.75}$ per day, where $\mathrm{kg}^{0.75}$ indicates metabolic BW (Van Es, 1975).

\section{Blood Collection and Analysis}

Blood was collected weekly from 3 wk prepartum until 7 wk postpartum. Blood samples were collected after the morning milking and between 3 and $1 \mathrm{~h}$ before the morning feeding. Blood $(10 \mathrm{~mL})$ was collected from the coccygeal vein or artery into evacuated EDTA tubes (Vacuette, Greiner BioOne, Kremsmunster, Austria). Blood samples were kept on ice before centrifugation for plasma isolation $\left(3,000 \times g\right.$ for $15 \mathrm{~min}$ at $\left.4^{\circ} \mathrm{C}\right)$. Plasma samples were stored at $-20^{\circ} \mathrm{C}$. Concentrations of FFA and BHB were measured enzymatically using Wako Chemicals kit no. 994-75409 (Neuss, Germany) and Randox Laboratories kit no. RB1007 (Ibach, Switzerland), respectively (Graber et al., 2012). The plasma glucose concentration was measured using BioMerieux kit no. 61269 (Marcy l'Etoile, France; Graber et al., 2012). The plasma insulin concentration was measured using EMD Millipore Corporation kit no. PI-12K (Billerica, MA). The plasma IGF-1 concentration was measured using Beckman Coulter kit no. A15729 (Fullerton, CA).

\section{Statistical Analyses}

Preliminary analysis showed that repeated use of the 6 cows in this experiment did not affect the results of this study. Statistical analyses were performed using a repeated measures analysis in a mixed linear model (PROC MIXED, SAS 9.3; SAS Institute Inc., 2011) with cow as the subject, considered as a random effect, for repeated weekly observations on individual cows. A first-order autoregressive covariance matrix was the best fit according to Akaike's corrected information criterion and was used to account for within-cow variation.

Data were analyzed separately for 3 periods of the experiment: prepartum, wk 1 to 3 postpartum, and wk 4 to 7 postpartum. Prepartum and during wk 1 to 3 postpartum, feed intake, EB, and plasma metabolites were analyzed for fixed effects of treatment (0-d DP or 30 -d DP), postpartum parity $(2, \geq 3)$, week relative to calving (wk -4 to -1 or wk 1 to 3 ), and their 2-way interaction effects. For wk 4 to 7 postpartum, milk production, milk composition, feed intake, EB, and plasma metabolites were analyzed for fixed effects of treatment (0-d DP-L, 0-d DP-S, or 30-d DP-S), postpartum parity $(2, \geq 3)$, week relative to calving (wk 4 to 7 ), and their 2-way interaction effects. Body condition score was analyzed using the same model but with month relative to calving rather than week relative to calving. Cows were blocked for calving date, milk yield in the previous lactation, and parity $(2, \geq 3)$ in the subsequent lactation. Block was included in all analyses as a random effect. All pairwise differences of least squares means for transition treatments and parities were assessed per week. The natural logarithm was calculated for plasma BHB and FFA concentration to approximate normality. Results are presented as least squares means with their standard error of the mean unless otherwise stated.

\section{RESULTS}

Between wk 1 and 7 postpartum, 5 cows were treated for milk fever (0-d DP-L, $\mathrm{n}=3$; 30-d DP-S, $\mathrm{n}=2$ ), 3 cows were treated for left displaced abomasum (0-d DP-L, $\mathrm{n}=1$; 30-d DP-S, $\mathrm{n}=2$ ), 2 cows were treated for ketosis (0-d DP-L, $\mathrm{n}=1$; 0 -d DP-S, $\mathrm{n}=1), 19$ cows were treated for clinical mastitis $(0-\mathrm{d}$ DP-L, $\mathrm{n}=6$; 0 -d DP-S, $\mathrm{n}=7 ; 30$-d DP-S, $\mathrm{n}=6), 12$ cows were treated for retained placenta (0-d DP-L, $\mathrm{n}=3$; 0-d DP-S, $\mathrm{n}=$ 5 ; 30-d DP-S, $\mathrm{n}=4)$, 15 cows were treated for chronic endometritis (0-d DP-L, $\mathrm{n}=2$; 0-d DP-S, $\mathrm{n}=7 ; 30-\mathrm{d}$ DP-S, $\mathrm{n}=6$ ), and 5 cows were treated for pyometra (0-d DP-L, $\mathrm{n}=2$; 0-d DP-S, $\mathrm{n}=1$; 30-d DP-S, $\mathrm{n}=2$ ).

\section{Milk Yield}

Prepartum, cows with a 0 -d DP produced $11.3 \pm$ $0.6 \mathrm{~kg} / \mathrm{d}$ of milk or $13.9 \pm 0.7 \mathrm{~kg} / \mathrm{d}$ of FPCM (Table $3)$. Total milk yield was $323 \pm 17 \mathrm{~kg}$ for cows with a $0-d$ DP in the 4 wk prepartum. Milk yield, FPCM yield, lactose content, and lactose, fat, and protein yields were greater and protein content was lower in cows with postpartum parity 2 than in cows with parity $\geq 3(P<0.01)$. An interaction was found between parity and week relative to calving for milk yield, FPCM yield, lactose, fat and protein contents, and lactose, fat, and protein yields. Milk and FPCM yields and lactose content were greatest in cows with parity 2 at 4 wk prepartum $(17.2 \pm 0.8 \mathrm{~kg} / \mathrm{d}, 20.4 \pm 0.9 \mathrm{~kg} / \mathrm{d}$, and 4.73 
VAN HOEIJ ET AL.

Table 3. Prepartum ${ }^{1}$ milk yield and milk composition of cows with a 0-d dry period (DP; LSM \pm SEM)

\begin{tabular}{|c|c|c|c|c|c|c|c|c|}
\hline \multirow[b]{2}{*}{ Item } & \multirow[b]{2}{*}{ 0-d DP } & \multirow[b]{2}{*}{ SEM } & \multicolumn{2}{|c|}{ Parity } & \multirow[b]{2}{*}{ SEM } & \multicolumn{3}{|c|}{$P$-value ${ }^{2}$} \\
\hline & & & 2 & $\geq 3$ & & $\mathrm{P}$ & W & $\mathrm{P} \times \mathrm{W}$ \\
\hline Cows (n) & 81 & & 40 & 41 & & & & \\
\hline Milk yield $(\mathrm{kg} / \mathrm{d})$ & 11.3 & 0.6 & 13.5 & 9.1 & 0.9 & $<0.01$ & $<0.01$ & $<0.01$ \\
\hline $\operatorname{FPCM}^{3}(\mathrm{~kg} / \mathrm{d})$ & 13.9 & 0.7 & 16.6 & 11.2 & 1.0 & $<0.01$ & $<0.01$ & $<0.01$ \\
\hline Lactose $(\%)$ & 4.37 & 0.05 & 4.67 & 4.08 & 0.08 & $<0.01$ & $<0.01$ & $<0.01$ \\
\hline Fat $(\%)$ & 5.20 & 0.08 & 5.36 & 5.05 & 0.11 & 0.06 & 0.03 & $<0.01$ \\
\hline Protein $(\%)$ & 5.61 & 0.13 & 5.25 & 5.97 & 0.18 & $<0.01$ & $<0.01$ & $<0.01$ \\
\hline Lactose $(\mathrm{kg} / \mathrm{d})$ & 0.52 & 0.03 & 0.64 & 0.40 & 0.04 & $<0.01$ & $<0.01$ & 0.01 \\
\hline Fat $(\mathrm{kg} / \mathrm{d})$ & 0.59 & 0.03 & 0.71 & 0.46 & 0.04 & $<0.01$ & $<0.01$ & 0.01 \\
\hline Protein $(\mathrm{kg} / \mathrm{d})$ & 0.55 & 0.03 & 0.63 & 0.47 & 0.04 & $<0.01$ & $<0.01$ & 0.02 \\
\hline
\end{tabular}

${ }^{1}$ Prepartum $=$ wk -4 to -1 before calving.

${ }^{2} \mathrm{P}=$ parity; $\mathrm{W}=$ week relative to calving.

${ }^{3} \mathrm{FPCM}=$ fat- and protein-corrected milk.

$\pm 0.06 \%$, respectively) and lowest in cows with parity $\geq 3$ at 1 wk prepartum $(5.7 \pm 0.9 \mathrm{~kg} / \mathrm{d}, 7.4 \pm 1.2 \mathrm{~kg} / \mathrm{d}$, and $3.56 \pm 0.13 \%$, respectively; $P<0.01$ ).

During wk 1 to 3 postpartum, milk fat yield was lower in cows with a 0 -d DP compared with cows with a 30 -d DP $(P<0.01$; Table 4$)$. During wk 1 to 3 , the effect of DP length on milk yield (Figure 1A), milk protein content (Figure 1B), and lactose yield (Figure 1C) depended on parity. Milk lactose content was lower in cows with parity $\geq 3$ compared with cows with parity $2(P<0.05)$. Milk and lactose yields were greater and milk protein content was lower in cows with parity $\geq 3$ after a $0-d$ DP compared with parity $2(P<0.05)$, whereas the effect of parity was not present in cows after a 30 -d DP $(P \geq 0.05)$.

During wk 4 to 7 postpartum, FPCM yield, milk lactose content, and milk lactose and fat yields were lower in 0-d DP-L and 0-d DP-S cows than in 30-d DP-S cows $(P<0.05$; Table 5$)$. During wk 4 to 7 , the effect of DP length on milk yield (Figure 1A), milk protein content (Figure 1B), and milk fat content (Figure 1D) depended on parity. Milk lactose content was lower in cows with parity $\geq 3$ compared with cows with parity $2(P<0.05)$. Milk and lactose yields were greater and milk protein content was lower in $0-\mathrm{d}$ DP-L and $0-\mathrm{d}$ DP-S cows with parity $\geq 3$ compared with parity $2(P$ $<0.05)$, whereas the effect of parity was not present for 30-d DP-S cows $(P \geq 0.05)$. Milk fat content was lower in 0-d DP-L and 0-d DP-S cows with parity $\geq 3$ compared with parity $2(P<0.05)$, whereas the effect of parity was not present for cows after a 30-d DP ( $P$ $\geq 0.05$ ). During wk 4 to 7 , there was an interaction between treatment and week relative to calving for milk yield and FPCM yield (Figure 2A) and milk fat yield (Figure 2B; $P<0.05$ ).

\section{DMI, EB, Metabolites, and Disease}

Prepartum, DMI, concentrate intake, basal ration intake, and energy intake (expressed per $\mathrm{kg}$ of metabolic

Table 4. Postpartum milk yield and milk composition of cows during wk 1 to 3 after a 0 - or 30 -d dry period (DP) ${ }^{1}$

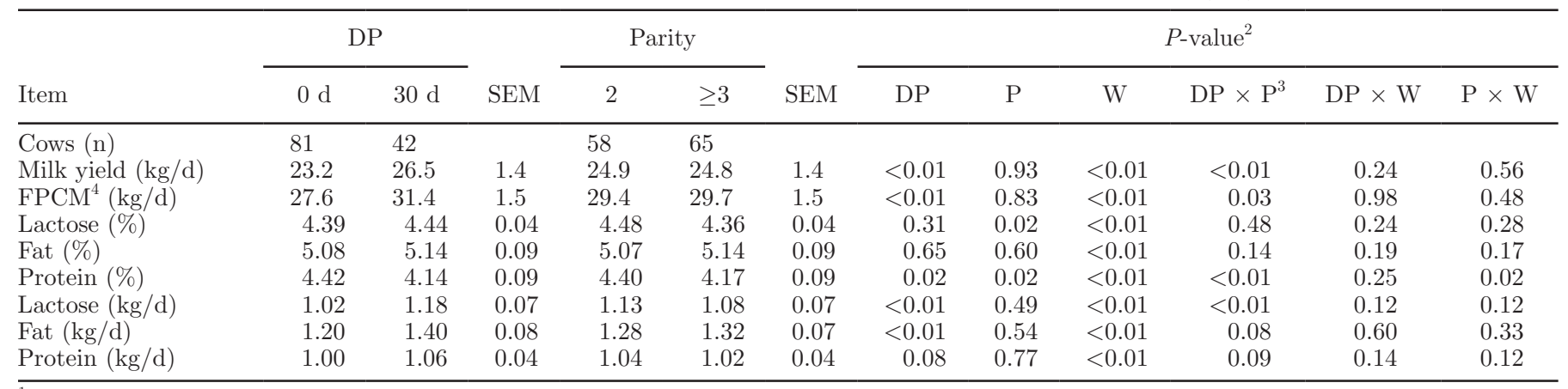

${ }^{1}$ Postpartum $=$ wk 1 to 3 after calving. Cows with a 0-d DP were provided either a low level of concentrate or the standard level of concentrate that cows with a $30-d \mathrm{DP}$ received (LSM $\pm \mathrm{SEM})$.

${ }^{2} \mathrm{P}=$ parity; $\mathrm{W}=$ week relative to calving.

${ }^{3}$ Interactions of treatment with parity $(\mathrm{T} \times \mathrm{P} ; \mathrm{P}<0.05)$ are shown in Figure 1.

${ }^{4} \mathrm{FPCM}=$ fat- and protein-corrected milk. 
BW) were lower in cows with a 30-d DP than in cows with a 0 -d DP $(P<0.01$; Table 6$)$. Plasma FFA and glucose concentrations were lower in cows with a 0 -d DP than in cows with a $30-d$ DP $(P<0.01)$. Plasma
BHB and insulin concentrations were greater in cows with a 0-d DP than in cows with a 30-d DP $(P<$ 0.05). Dry matter intake, basal ration intake, and $\mathrm{BW}$ were lower in cows with parity 2 than in cows with
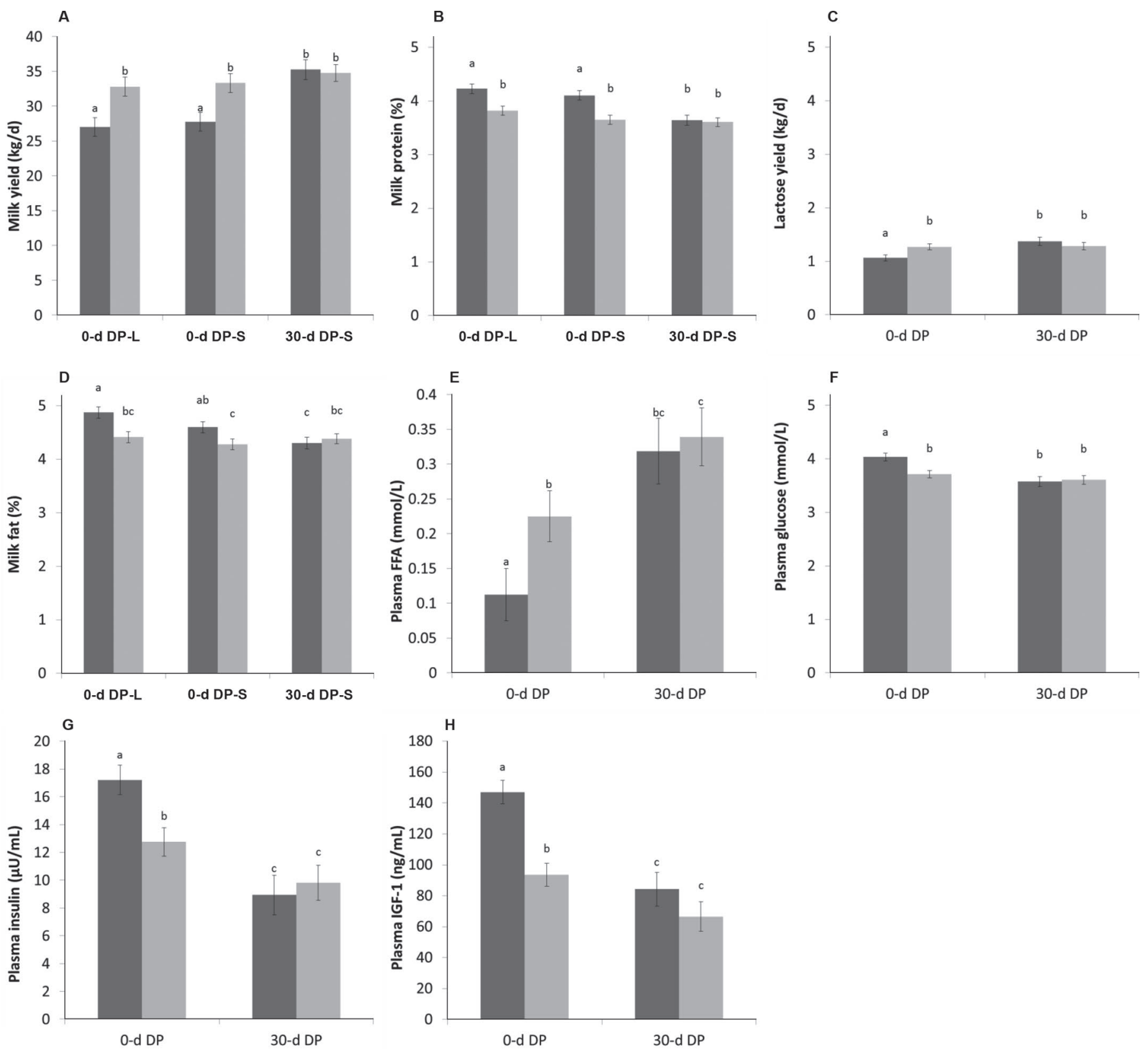

Figure 1. Interaction between postpartum treatment and postpartum parity ( 2 in dark gray; $\geq 3$ in light gray) for (A) milk yield during wk 1 to 3 and wk 4 to 7 postpartum, (B) milk protein content during wk 1 to 3 and wk 4 to 7 postpartum, (C) lactose yield during wk 1 to 3 postpartum, (D) milk fat content during wk 4 to 7 postpartum, (E) plasma free fatty acid (FFA) concentration during wk 1 to 3 postpartum, (F) plasma glucose concentration during wk 1 to 3 postpartum, $(\mathrm{G})$ plasma insulin concentration during wk 1 to 3 postpartum, and (H) plasma IGF-1 concentration during wk 1 to 3 postpartum. Treatments wk 1 to 3: 0-d dry period (DP) or 30-d DP. Treatments wk 4 to 7: 0-d DP and a low level of concentrate based on the requirement for cows' expected milk yield (0-d DP-L); 0-d DP and a standard level of concentrate (0-d DP-S); and 30-d DP and a standard level of concentrate based on the requirement for cows' expected milk yield (30-d DP-S). Values with different letters $(\mathrm{a}-\mathrm{c})$ differ $(P<0.05)$. Results are presented as $\mathrm{LSM} \pm \mathrm{SEM}$. 
parity $\geq 3(P<0.05)$. Energy intake (expressed per $\mathrm{kg}$ of metabolic BW) was greater in cows with parity 2 than in cows with parity $\geq 3(P<0.01)$. The plasma insulin concentration was lower in cows with parity 2 than in cows with parity $\geq 3(P<0.05)$. Energy balance was not different between DP lengths or between parities $(P \geq 0.05)$. The interaction of DP length with week relative to calving was present for DMI (Figure $2 \mathrm{E}$ ), concentrate intake (Figure $2 \mathrm{~F}$ ), basal ration intake (Figure 2G), energy intake (Figure 3A), BW, BCS, and plasma BHB concentration (Figure 3C; $P<0.05$ ).

During wk 1 to 3 postpartum, DMI, concentrate intake, basal ration intake, and energy intake were greater in cows with a 0-d DP compared with cows with a 30-d DP $(P<0.01$; Table 7$)$. Plasma BHB concentration was lower in cows with a 0-d DP compared with cows with a 30 -d DP $(P<0.01)$. Energy intake was greater but BW was lower in cows with parity 2 compared with cows with parity $\geq 3(P<0.01)$. During wk 1 to 3 postpartum, the effect of DP length on EB, plasma FFA (Figure 1E), glucose (Figure 1F), insulin (Figure 1G), and IGF-1 (Figure 1H) concentrations depended on parity. Plasma FFA concentration was greater in cows with parity $\geq 3$ after a 0 -d DP compared with parity 2 $(P<0.05)$, whereas the effect of parity was not present for cows after a 30-d DP $(P \geq 0.05)$. Plasma glucose, insulin, and IGF-1 concentrations were lower in cows with parity $\geq 3$ after a 0 -d DP compared with parity 2 $(P<0.05)$, whereas the effect of parity was not present for cows after a 30-d DP $(P \geq 0.05)$. Energy intake was greater but BW was lower in cows with parity 2 compared with cows with parity $\geq 3(P<0.01)$. During wk 1 to 3 postpartum, there was an interaction of treatment with week relative to calving for DMI (Figure $2 \mathrm{C}$ ), concentrate intake (Figure 2D), basal ration intake (Figure 2E), BW, plasma BHB (Figure 3A), and IGF-1 concentration (Figure 3B; $P<0.05$ ). The interaction of parity with week relative to calving revealed that BW decreased with week relative to calving in cows with parity $\geq 3$ and increased with week relative to calving in cows with parity 2 between wk 1 and $3(P<0.01)$.

During wk 4 to 7 postpartum, concentrate and energy intake were lower in 0-d DP-L cows than in 0-d DP-S or 30-d DP-S cows (Table 8). Basal ration intake, EB, BW, and plasma glucose, insulin, and IGF-1 concentrations were greater and plasma FFA concentration was lower in 0-d DP-L and 0-d DP-S cows compared with 30-d DP-S cows $(P<0.05$; Table 8$)$. Energy intake and plasma glucose and IGF-1 concentrations were greater but DMI, basal ration intake, BW, and plasma BHB concentration were lower in cows with parity 2 compared with cows with parity $\geq 3(P<0.05)$. During wk 4 to 7 , there was an interaction between treatment and week relative to calving for DMI (Figure 2C), concen- 

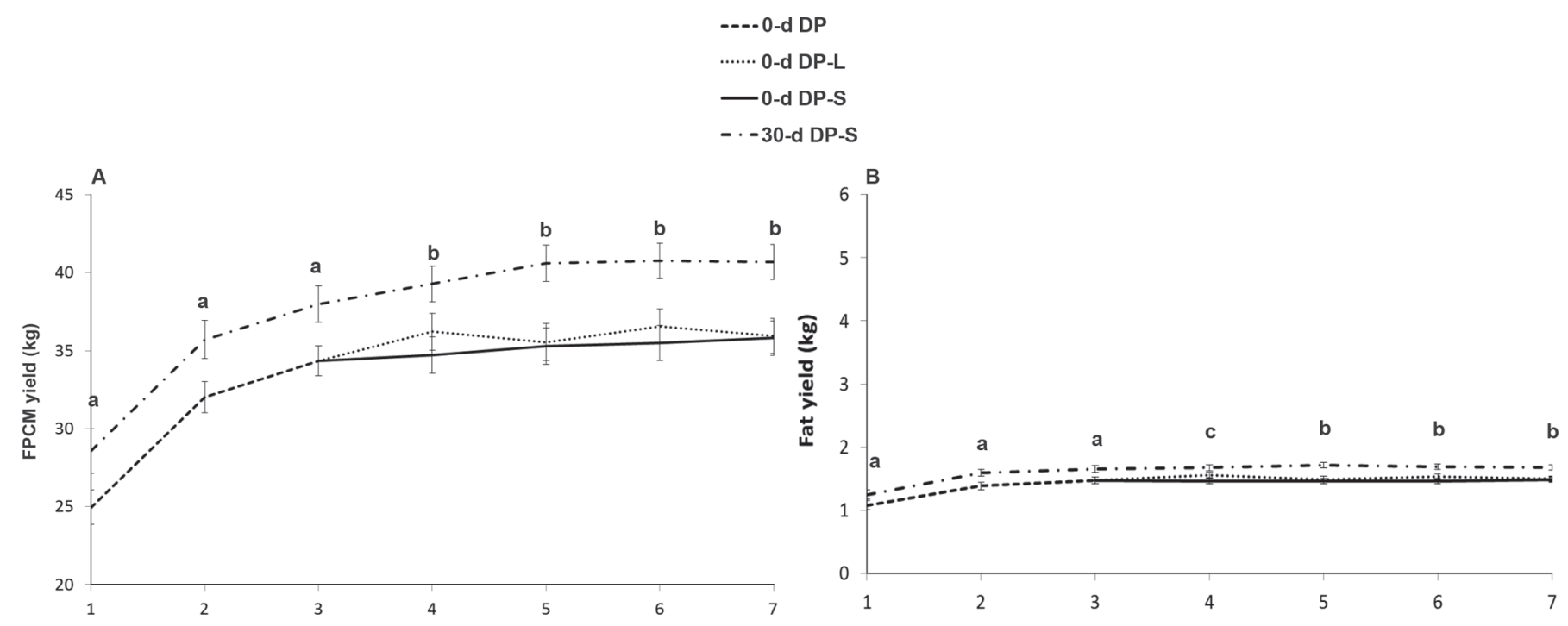

C
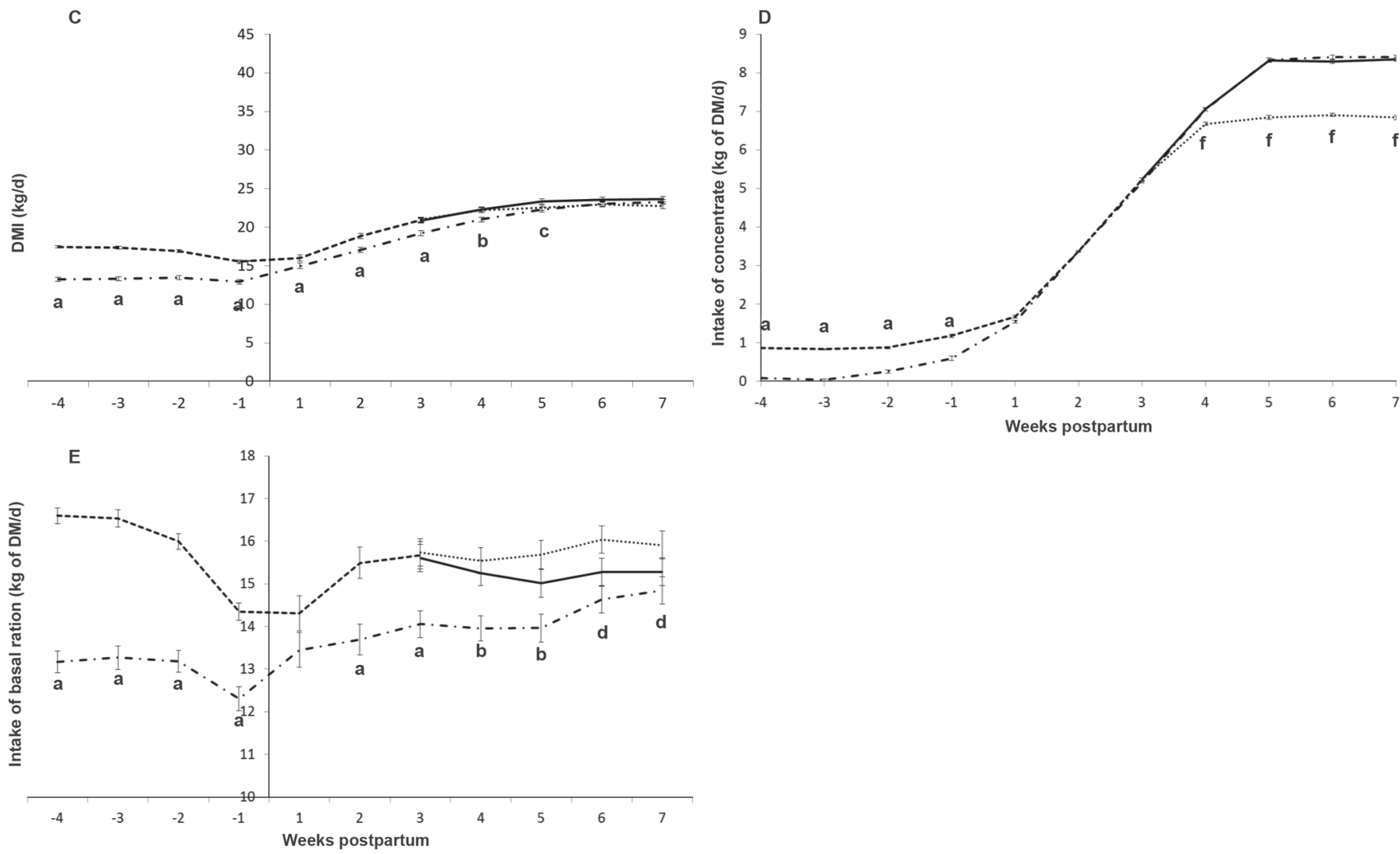

Figure 2. The effect of treatment on (A) fat- and protein-corrected milk (FPCM) yield, (B) fat yield, (C) DMI, (D) intake of concentrate, and (E) intake of basal ration. Treatments: 0-d dry period (DP) and a low level of concentrate based on the requirement for cows' expected milk yield (0-d DP-L); 0-d DP and a standard level of concentrate (0-d DP-S); and 30-d DP and a standard level of concentrate based on the requirement for cows' expected milk yield (30-d DP-S). 0-d DP represents the average of both 0-d DP-L and 0-d DP-S prepartum. [a] 0-d DP differs from 30-d DP. [b] 30-d DP-S differs from 0-d DP-L and 0-d DP-S. [c] 30-d DP-S differs from 0-d DP-S but not from 0-d DP-L. [d] 0-d DP-L differs from 30-d DP-S but not from 0-d DP-S. [f] 0-d DP-L differs from 0-d DP-S but not from 30-d DP-S. Data were analyzed separately for 3 periods of the experiment: prepartum, wk 1 to 3 postpartum, and wk 4 to 7 postpartum. Results are presented as LSM \pm SEM. 
VAN HOEIJ ET AL.

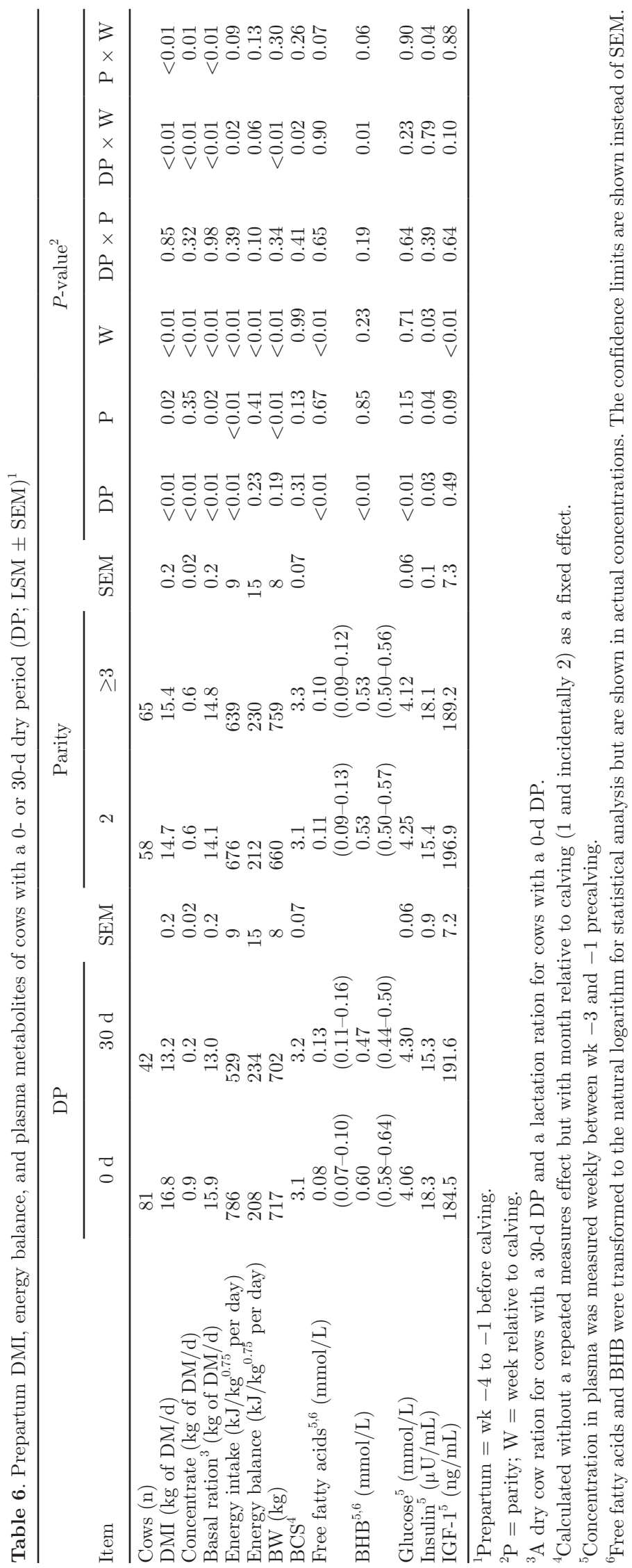




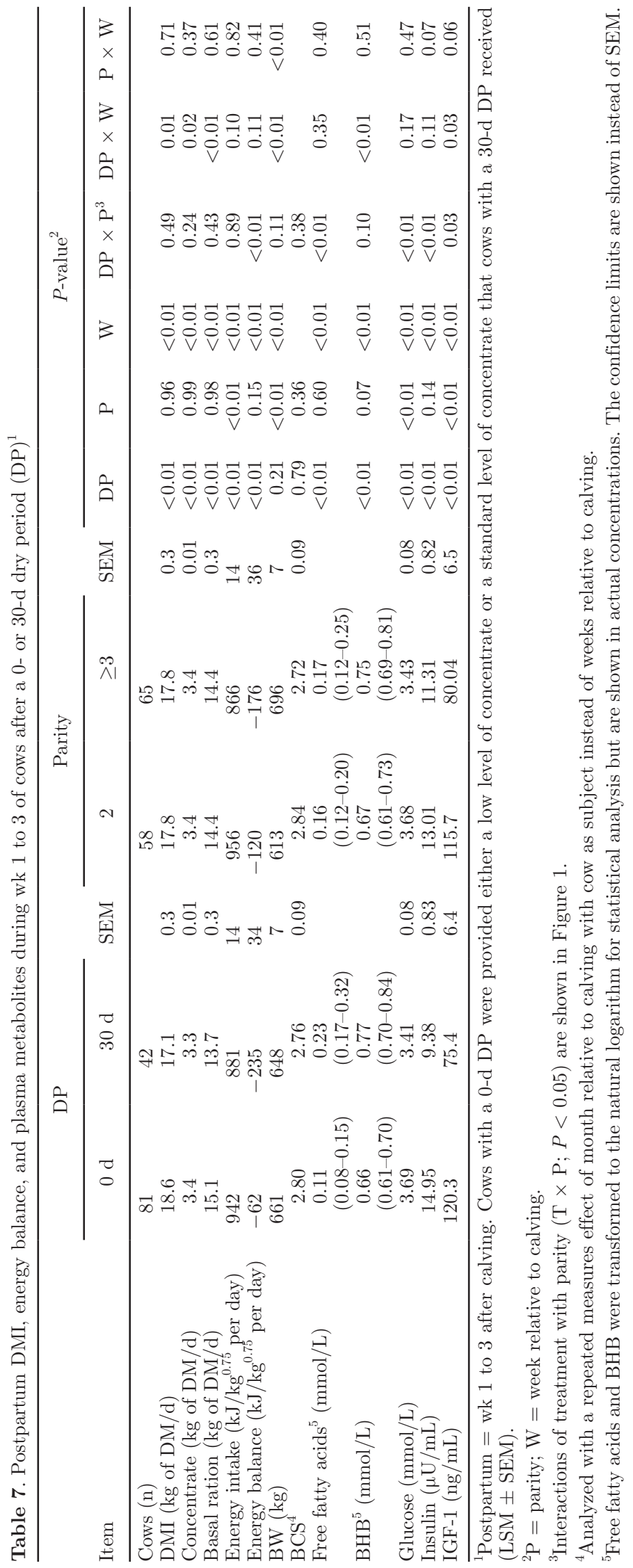


VAN HOEIJ ET AL.

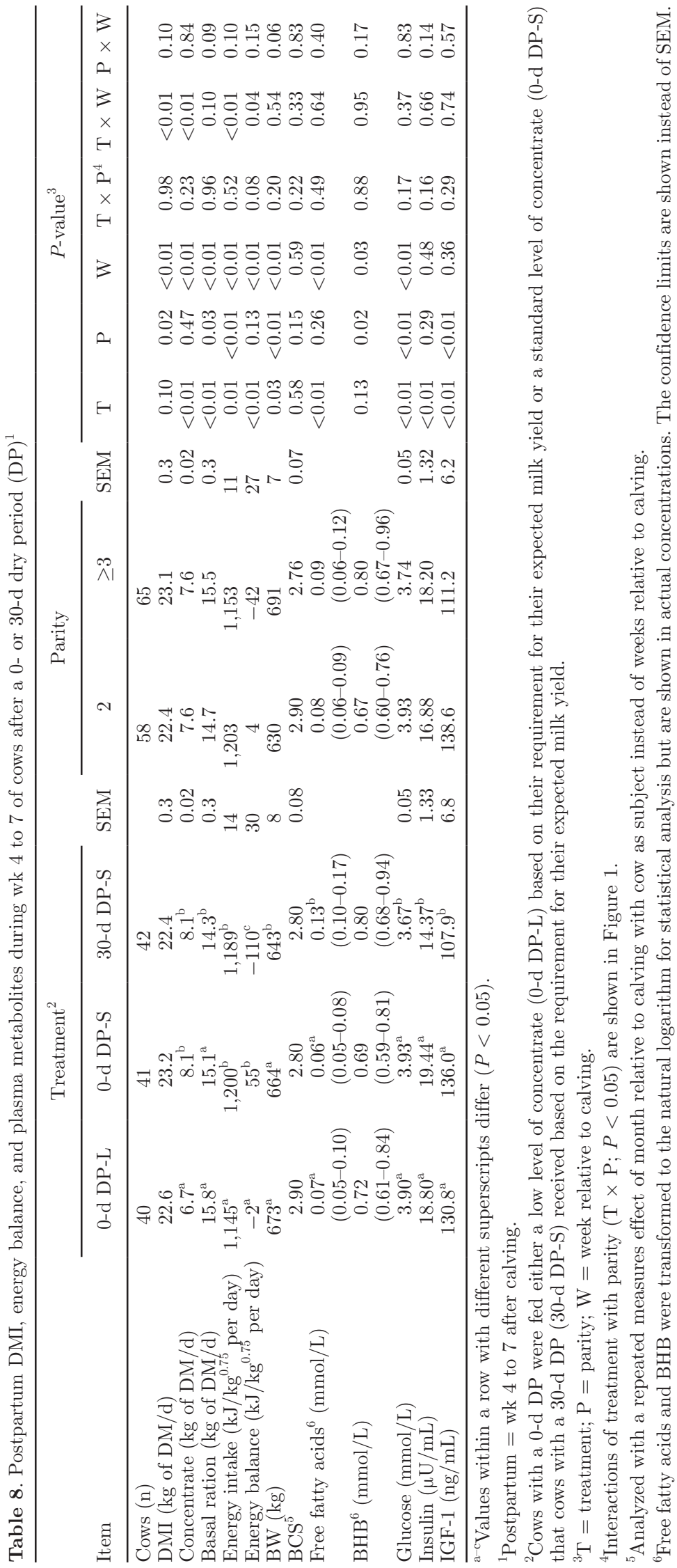




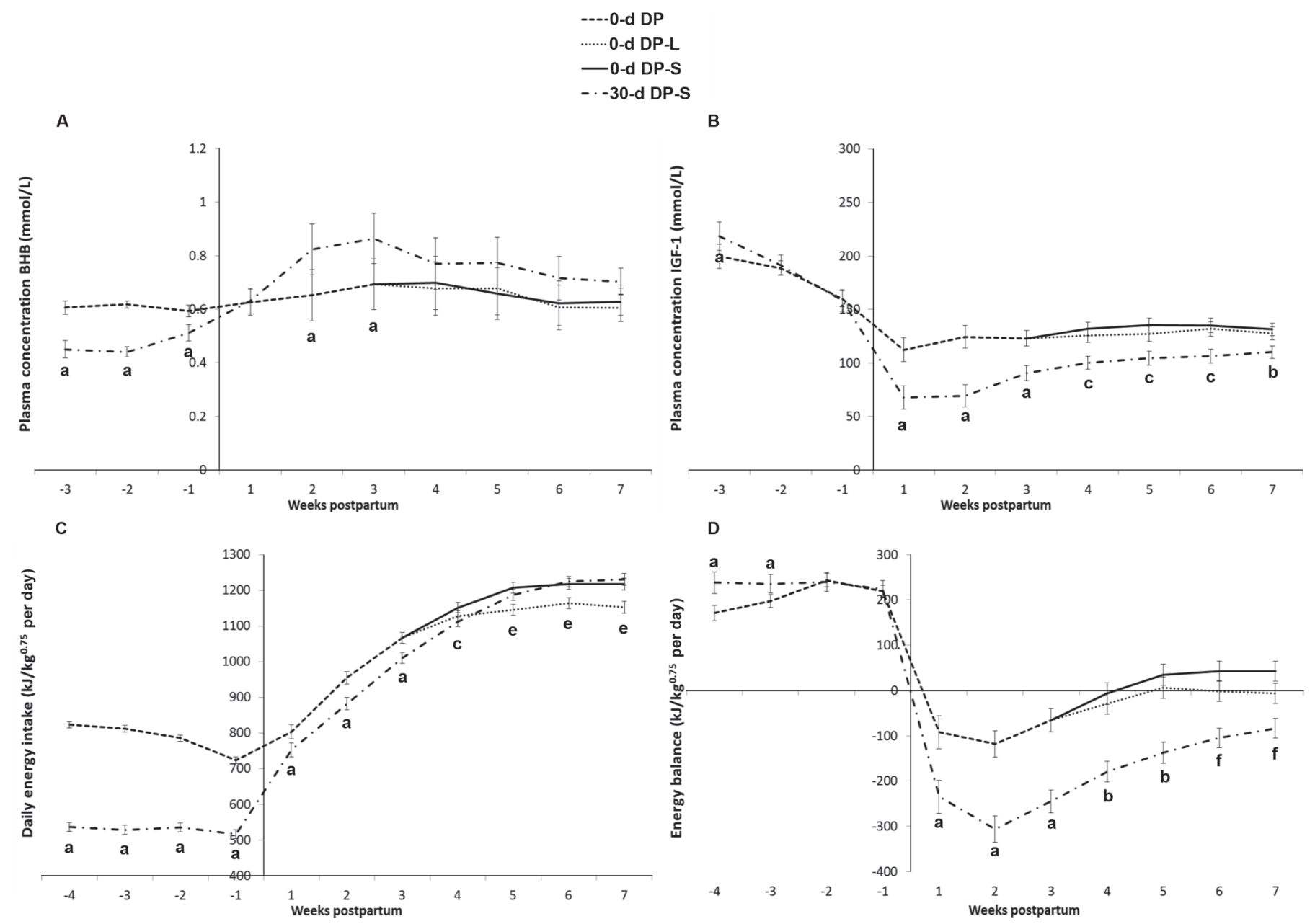

Figure 3. The effect of treatment on (A) plasma concentration of BHB, (B) plasma concentration of IGF-1, (C) daily energy intake, and (D) energy balance. Treatments: 0-d dry period (DP) and a low level of concentrate based on the requirement for cows' expected milk yield (0-d DP-L); 0-d DP and a standard level of concentrate (0-d DP-S); and 30-d DP and a standard level of concentrate based on the requirement for cows' expected milk yield (30-d DP-S). 0-d DP represents the average of both 0-d DP-L and 0-d DP-S prepartum. [a] 0-d DP differs from 30-d DP. [b] 30-d DP-S differs from 0-d DP-L and 0-d DP-S. [c] 30-d DP-S differs from 0-d DP-S but not from 0-d DP-L. [e] 0-d DP-L differs from 0-d DP-S and 30-d DP-S. [f] 0-d DP-L, 0-d DP-S, and 30-d DP-S differ from each other. Data were analyzed separately for 3 periods of the experiment: prepartum, wk 1 to 3 postpartum, and wk 4 to 7 postpartum. Results are presented as LSM \pm SEM.

trate intake (Figure 2D), energy intake (Figure 3C), and EB (Figure 3D; $P<0.05$ ).

\section{DISCUSSION}

Reducing the level of concentrate in 0-d DP-L cows did not affect EB in early lactation in wk 4 and 5 postpartum compared with 0-d DP-S cows. After the concentrate contrast was complete (from wk 5 postpartum onward), EB of 0-d DP-L cows was lower in wk 6 and 7 postpartum compared with 0-d DP-S cows. In the current study, the lower concentrate intake of 0-d DP-L cows did not affect average DMI or NE intake in wk 4 to 7 postpartum. When the concentrate contrast was complete, 0-d DP-L cows consumed $19 \%$ less concentrate $(6.8 \pm 0.0$ vs. $8.4 \pm 0.0 \mathrm{~kg}$ of $\mathrm{DM} / \mathrm{d})$, which resulted in a $5 \%$ lower energy intake $(1,151 \pm 14$ vs. $1,216 \pm 14 \mathrm{~kJ} / \mathrm{kg}^{0.75}$ per day) compared with 0 -d DP-S cows. In earlier studies, a lower concentrate level resulted in lower DMI and lower NE intake (Reist et al., 2003; Kokkonen et al., 2004; Zbinden et al., 2016). The differences in concentrate level between treatment groups in these studies were as large as $20 \%$ of individual requirements. These studies showed that reduction of concentrate level resulted in a small reduction in ECM (Reist et al., 2003; Kokkonen et al., 2004). In the current study, when the concentrate contrast was complete, milk yield, FPCM yield, and yield of milk components were not different between 0-d DP-L and 0 -d DP-S cows. The level of concentrate for cows with 
a 0-d DP can thus be lowered without an effect on average milk yield in wk 1 to 7 postpartum, although EB was lower in wk 6 and 7 for cows with a lower level of concentrate.

The absence of an effect of concentrate level (0-d DP-L vs. 0-d DP-S) on total DMI in wk 4 to 7 postpartum is caused by a numerically greater consumption of the basal ration of $0-\mathrm{d}$ DP-L cows compared with $0-\mathrm{d}$ DP-S cows. The 0-d DP-L cows tended to consume $4 \%$ more basal ration when the concentrate contrast was complete, which partially compensated for the lower concentrate intake. This partial compensation of lower concentrate intake $(6.8 \pm 0.0$ vs. $8.4 \pm 0.0 \mathrm{~kg} / \mathrm{d})$ with a greater basal ration intake $(15.8 \pm 0.3$ vs. $15.1 \pm 0.3$ $\mathrm{kg} / \mathrm{d})$ resulted in an equal DMI $(22.6 \pm 0.3$ vs. $23.2 \pm$ $0.3 \mathrm{~kg} / \mathrm{d}$ ) between 0-d DP-L cows and 0-d DP-S cows. Similarly, Dieho et al. (2016) reported that a daily difference in concentrate supply of $6.8 \mathrm{~kg}$ of $\mathrm{DM} / \mathrm{d}(\mathrm{d}$ 16 relative to calving) versus $3.3 \mathrm{~kg}$ of $\mathrm{DM} / \mathrm{d}$ (d 30 relative to calving) did not affect total DMI because animals receiving a lower concentrate supply increased their intake of the basal ration. Compensation of lower concentrate with basal ration can occur only to a certain extent due to the difference in satiety value of concentrate versus basal ration (Faverdin et al., 1991). The satiety value of a feed indicates the extent to which a feed limits intake and is calculated based on feed chemical composition (DM, CP, crude fiber, ash, sugar, and starch) and in vitro feed digestibility (Zom et al., 2012). In the current study, the satiety value of the basal ration was $0.92 / \mathrm{kg}$ of $\mathrm{DM}$ and the satiety value of the concentrate was $0.35 / \mathrm{kg}$ of DM (Zom et al., 2012). Based on these satiety values, the reduced level of concentrate $(1.6 \mathrm{~kg}$ of $\mathrm{DM} / \mathrm{d})$ can be expected to result in an increase of $0.6 \mathrm{~kg}$ of $\mathrm{DM} / \mathrm{d}$ of basal lactation ration. In the current study, $0-\mathrm{d}$ DP-L cows consumed $0.6 \mathrm{~kg}$ of DM/d more basal lactation ration than did 0-d DP-S cows. Therefore, the estimated satiety value of the basal ration is similar to the actual satiety value of the basal ration. The partial compensation of concentrate intake with basal ration intake in 0 -d DP-L cows results in sufficient energy intake to provide enough energy for milk yield. The lower concentrate intake nevertheless tended to decrease EB and increase milk fat content when the concentrate contrast was complete for 0-d DP-L cows compared with 0-d DP-S cows. Feeding a reduced level of concentrate after a 0-d DP may be beneficial for roughage intake and rumination and may be relevant to prevent subacute ruminal acidosis in early lactation (González et al., 2012). Moreover, reduction of the level of concentrate may also reduce feed costs.

Postpartum, EB of cows with a 30-d DP was more negative than that of cows with a $0-d$ DP, which is in line with previous studies (Rastani et al., 2005; Van Knegsel et al., 2014). The more negative EB of cows with a 30-d DP occurred earlier mainly because of the greater yield of milk and milk components in these cows compared with cows with a 0-d DP. The greater milk yield of cows with a $30-\mathrm{d}$ DP is possibly related to greater renewal of mammary cells during the DP (Capuco et al., 1997). Additionally, in the current study, postpartum DMI in wk 1 to 7 was $5 \%$ lower in cows with a $30-\mathrm{d}$ DP $(20.1 \pm 0.3 \mathrm{~kg} / \mathrm{d})$ compared with cows with a 0 -d DP $(21.1 \pm 0.3 \mathrm{~kg} / \mathrm{d})$, which is in line with earlier work (Rastani et al., 2005). In the current study, during wk 5 to 7 postpartum, DMI and energy intake of 30-d DP-S cows did not differ from that of 0 -d DP-S cows. Cows with a 30-d DP may have a less regular feeding pattern in the first week postpartum compared with cows with a 0-d DP as a result of more stressors, such as greater milk production, the transition from a dry cow ration to a lactation ration, and the transition to another social group (Huzzey et al., 2005). The more negative EB of cows with a 30-d DP was reflected in greater plasma FFA and BHB concentrations and lower plasma glucose, insulin, and IGF-1 concentrations compared with cows with a $0-d$ DP. A metabolic state with a low plasma FFA concentration is related to a greater plasma insulin concentration that allows greater hepatic IGF-1 production (Lucy, 2004). By omitting the DP in the current study, the plasma insulin concentration was greater than it was after a short DP. This likely resulted in greater IGF-1 concentration and an improved EB and is consistent with other studies (de Feu et al., 2009; Chen et al., 2015).

Prepartum, plasma BHB concentration was greater in cows with a 0-d DP than in cows with a $30-d$ DP, in line with Chen et al. (2015). This is possibly explained by the greater prepartum DMI and different ration composition in cows with a 0-d DP compared with cows with a 30-d DP. The greater DMI of cows with a $0-d$ DP may have increased the production of VFA in the rumen, including ruminal butyrate (Bergman, 1990). Greater ruminal butyrate formation contributes to a greater plasma BHB concentration (Bergman, 1990; Huhtanen et al., 1993; Miettinen and Huhtanen, 1996). Prepartum, the plasma FFA concentration was lower in cows with a 0 -d DP than in cows with a 30-d DP, which is in line with some earlier studies (Andersen et al., 2005; de Feu et al., 2009) but not all (Rastani et al., 2005; Schlamberger et al., 2010). Prepartum, FFA are partly removed from the body via milk of cows with a 0 -d DP, whereas FFA have to be fully metabolized in the body of cows with a $30-\mathrm{d}$ DP.

Prepartum, cows with parity 2 had lower DMI, lower basal ration intake, lower BW, and lower BCS but 
greater energy intake compared with cows with parity $\geq 3$. Cows with parity 2 have a lower feed intake capacity (unit of feed per unit of time) than cows with parity $\geq 3$ when expressed per unit of metabolic BW (CVB, 2011). In the current study, cows with parity 2 nevertheless had a greater DMI when DMI was expressed per kilogram of metabolic BW compared with cows with parity $\geq 3$ (0.17 vs. $0.16 \mathrm{~kg}$ of $\mathrm{DM} / \mathrm{kg}^{0.75}$ per day; $P$ $<0.01)$. The greater DMI per kilogram of metabolic $\mathrm{BW}$ resulted in a greater energy intake per kilogram of metabolic BW in cows with parity 2 than in cows with parity $\geq 3$. Cows with parity 2 and a 0 -d DP had the lowest milk yield in subsequent lactation compared with cows with parity 2 and a 30-d DP or cows with parity $\geq 3$. Earlier studies also showed that omitting the DP of cows with parity 2 resulted in greater milk yield reduction in the subsequent lactation compared with cows with parity $\geq 3$ (Annen et al., 2004; Santschi et al., 2011; Steeneveld et al., 2014). Cows with parity 2 may need a short or conventional DP for body and mammary growth (Annen et al., 2004).

Postpartum, energy intake per kilogram of metabolic BW, EB, and plasma glucose and IGF-1 concentrations were greater in cows with parity 2 compared with cows with parity $\geq 3$. Cows with parity 2 also had lower plasma FFA and BHB concentrations compared with cows with parity $\geq 3$, which allows coupling of the somatotropic axis. In the somatotropic axis, insulin acts opposite to growth hormone $(\mathbf{G H})$. Insulin allows $\mathrm{GH}$ to bind to the GH receptor in the liver, which stimulates IGF-1 synthesis in the liver. Liver IGF-1 inhibits GH-releasing hormone from the hypothalamus and thus inhibits GH release from the pituitary gland. Cows with parity 2 nevertheless already have a greater plasma GH concentration, which is related to their priority for growth (Kertz et al., 1997; Lucy, 2011). The greater plasma insulin concentration in the presence of a greater plasma GH concentration in cows with parity 2 resulted in more coupling of the somatotropic axis and a greater IGF-1 concentration (Lucy, 2011). The lower plasma IGF-1 concentration of cows with parity $\geq 3$ was most likely the result of a more negative EB because of greater milk production compared with cows with parity 2. Cows adapt to a more negative EB by a greater degree of uncoupling their somatotropic axis related to the low plasma insulin concentration (Gross and Bruckmaier, 2015; Zbinden et al., 2016). Uncoupling of the somatotropic axis resulted in uninhibited release of GH (Lucy, 2004). The released GH can nevertheless not bind its receptor in the liver, which results in lower IGF-1 synthesis in the liver of cows with parity $\geq 3$. In earlier studies, greater milk production was negatively related to the plasma concentration of IGF-1 (Grala et al., 2011; Gross and Bruckmaier, 2015). In contrast, the plasma IGF-1 concentration may be greater as a result of a greater plasma insulin concentration. Insulin may reduce persistency of lactation through its inhibition of GH through IGF-1 (Lucy, 2008; Roche et al., 2009). A greater plasma insulin concentration is related to overconditioning (Roche et al., 2009), which is a risk in cows with a 0-d DP in late lactation (Chen et al., 2016). The current study, however, focused only on the first 7 wk in lactation, during which no effect of treatment on BCS was observed. Studies are ongoing to evaluate the effect of dietary energy source and dietary energy level on body condition and persistency of lactation in cows with a 0 -d or $30-d$ DP.

\section{CONCLUSIONS}

A 0-d DP reduced milk production and improved the EB and metabolic status of cows in early lactation compared with a 30-d DP. Reducing the level of concentrate for cows with a $0-\mathrm{d}$ DP increased basal ration intake and milk fat content and reduced energy intake and EB in wk 6 and 7 but did not affect FPCM yield or plasma FFA and BHB concentrations in early lactation compared with cows with a 0-d DP and a standard concentrate level. Although feeding a reduced level of concentrate in cows after a 0-d DP increased milk fat content and reduced EB in early lactation, it may prevent fattening in mid and late lactation, increase roughage intake, stimulate rumination, and reduce feed costs.

\section{ACKNOWLEDGMENTS}

The authors thank DairyNL (Zuivel NL; organization of the Dutch dairy supply chain, The Hague, the Netherlands) and the Dutch Ministry of Economic Affairs (EZ, The Hague, the Netherlands) for financing this study. This study is part of the Public-Private Partnership "Sustainable Dairy Chain" (Duurzame Zuivelketen), The Hague, the Netherlands. The authors also thank Danny de Koning (Wageningen University and Research, Wageningen, the Netherlands) for his assistance with the statistical analyses and Rudi Koopmanschap and the Veterinary Physiology Group of the University of Bern (Switzerland) for their technical support and laboratory analyses during the experiment.

\section{REFERENCES}

Andersen, J. B., T. G. Madsen, T. Larsen, K. L. Ingvartsen, and M. O. Nielsen. 2005. The effects of dry period versus continuous lactation on metabolic status and performance in periparturient cows. J. Dairy Sci. 88:3530-3541. https://doi.org/10.3168/jds.S00220302(05)73038-1. 
Annen, E. L., R. J. Collier, M. A. McGuire, J. L. Vicini, J. M. Ballam, and M. J. Lormore. 2004. Effect of modified dry period lengths and bovine somatotropin on yield and composition of milk from dairy cows. J. Dairy Sci. 87:3746-3761. https://doi.org/10.3168/ jds.S0022-0302(04)73513-4.

Bergman, E. N. 1990. Energy contributions of volatile fatty acids from the gastrointestinal tract in various species. Physiol. Rev. 70:567-590.

Bernier-Dodier, P., L. Delbecchi, G. F. Wagner, B. G. Talbot, and P. Lacasse. 2010. Effect of milking frequency on lactation persistency and mammary gland remodeling in mid-lactation cows. J. Dairy Sci. 93:555-564. https://doi.org/10.3168/jds.2009-2320.

Capuco, A. V., R. M. Akers, and J. J. Smith. 1997. Mammary growth in Holstein cows during the dry period: Quantification of nucleic acids and histology. J. Dairy Sci. 80:477-487. https://doi. org/10.3168/jds.S0022-0302(97)75960-5.

Chen, J., J. J. Gross, H. A. van Dorland, G. J. Remmelink, R. M. Bruckmaier, B. Kemp, and A. T. M. van Knegsel. 2015. Effects of dry period length and dietary energy source on metabolic status and hepatic gene expression of dairy cows in early lactation. J. Dairy Sci. 98:1033-1045. https://doi.org/10.3168/jds.2014-8612.

Chen, J., G. J. Remmelink, J. J. Gross, R. M. Bruckmaier, B. Kemp, and A. T. M. van Knegsel. 2016. Effects of dry period length and dietary energy source on milk yield, energy balance, and metabolic status of dairy cows over 2 consecutive years: Effects in the second year. J. Dairy Sci. 99:4826-4838. https://doi.org/10.3168/ jds.2015-10742.

CVB (Centraal Veevoeder Bureau). 2011. Chemische Samenstellingen en Nutritionele Waarden van Voedermiddelen (in Dutch). Productschap Diervoeder, Centraal Veevoeder Bureau, The Hague, the Netherlands.

de Feu, M. A., A. C. Evans, P. Lonergan, and S. T. Butler. 2009. The effect of dry period duration and dietary energy density on milk production, bioenergetic status, and postpartum ovarian function in Holstein-Friesian dairy cows. J. Dairy Sci. 92:6011-6022. https://doi.org/10.3168/jds.2009-2374.

Dieho, K., A. Bannink, I. A. L. Geurts, J. T. Schonewille, G. Gort, and J. Dijkstra. 2016. Morphological adaptation of rumen papillae during the dry period and early lactation as affected by rate of increase of concentrate allowance. J. Dairy Sci. 99:2339-2352. https://doi.org/10.3168/jds.2015-9837.

EC (European Commission). 2009. European Commission Regulation (EC) No 152/2009 of 27 January 2009 laying down the methods of sampling and analysis for the official control of feed. Official Journal of the European Union L/54. 26.2.2009. European Commission, Brussels, Belgium.

EEC (European Economic Community). 1971. FIRST COMMISSION DIRECTIVE of 15 June 1971 establishing Community methods of analysis for the official control of feeding-stuffs (71/250/EEC). Official Journal EC, 12/7/71

Faverdin, P., J. P. Dulphy, J. B. Coulon, R. Vérité, J. P. Garel, J. Rouel, and B. Marquis. 1991. Substitution of roughage by concentrates for dairy cows. Livest. Prod. Sci. 27:137-156. https://doi. org/10.1016/0301-6226(91)90092-5.

Ferguson, J. D., D. T. Galligan, and N. Thomsen. 1994. Principal descriptors of body condition in Holstein cows. J. Dairy Sci. 77:26952703. https://doi.org/10.3168/jds.S0022-0302(94)77212-X.

González, L. A., X. Manteca, S. Calsamiglia, K. S. SchwartzkopfGenswein, and A. Ferret. 2012. Ruminal acidosis in feedlot cattle: Interplay between feed ingredients, rumen function and feeding behavior (a review). Anim. Feed Sci. Technol. 172:66-79. https:// doi.org/10.1016/j.anifeedsci.2011.12.009.

Graber, M., S. Kohler, A. Müller, K. Burgermeister, T. Kaufmann, R. M. Bruckmaier, and H. A. van Dorland. 2012. Identification of plasma and hepatic parameters related to metabolic robustness in dairy cows. J. Anim. Physiol. Anim. Nutr. (Berl.) 96:75-84. https://doi.org/10.1111/j.1439-0396.2010.01124.x.

Grala, T. M., M. C. Lucy, C. V. C. Phyn, A. J. Sheahan, J. M. Lee, and J. R. Roche. 2011. Somatotropic axis and concentrate supplementation in grazing dairy cows of genetically diverse origin. J. Dairy Sci. 94:303-315. https://doi.org/10.3168/jds.2010-3773.
Gross, J. J., and R. M. Bruckmaier. 2015. Repeatability of metabolic responses to a nutrient deficiency in early and mid lactation and implications for robustness of dairy cows. J. Dairy Sci. 98:86348643. https://doi.org/10.3168/jds.2014-9246.

Huhtanen, P., H. Miettinen, and M. Ylinen. 1993. Effect of increasing ruminal butyrate on milk yield and blood constituents in dairy cows fed a grass silage-based diet. J. Dairy Sci. 76:1114-1124. https://doi.org/10.3168/jds.S0022-0302(93)77440-8.

Huzzey, J. M., M. A. G. Von Keyserlingk, and D. M. Weary. 2005. Changes in feeding, drinking and standing behavior in dairy cows during the transition period. J. Dairy Sci. 88:2454-2461. https:// doi.org/10.3168/jds.S0022-0302(05)72923-4.

ISO 15914. 2004. Animal feeding stuffs. Enzymatic determination of total starch content. International Organization of Standardization, Geneva, Switzerland.

ISO 16472. 2006. Animal Feeding Stuffs-Determination of AmylaseTreated Neutral Detergent Fibre content (aNDF). International Organization of Standardization, Geneva, Switzerland.

ISO 9622. 2013. Milk and liquid milk products. Guidelines for the application of mid-infrared spectrometry. 2:14. International Organization of Standardization, Geneva, Switzerland.

ISO 13906. 2008. Animal feeding stuffs. Determination of acid detergent fiber $(\mathrm{ADF})$ and acid detergent lignin (ADL) contents. International Organization of Standardization, Geneva, Switzerland

Kertz, A. F., L. F. Reutzel, B. A. Barton, and R. L. Ely. 1997. Body weight, body condition score, and wither height of prepartum Holstein cows and birth weight and sex of calves by parity: A database and summary. J. Dairy Sci. 80:525-529. https://doi.org/10.3168/ jds.S0022-0302(97)75966-6.

Kokkonen, T., A. Tesfa, M. Tuori, and L. Syrjala-Qvist. 2004. Concentrate feeding strategy of dairy cows during transition period. Livest. Prod. Sci. 86:239-251. https://doi.org/10.1016/j. livprodsci.2003.09.003.

Lucy, M. C. 2004. Mechanisms linking the somatotropic axis with insulin: Lessons from the postpartum dairy cow. Proc. New Zealand Soc. Anim. Prod. 64:19-23.

Lucy, M. C. 2008. Functional differences in the growth hormone and insulin-like growth factor axis in cattle and pigs: Implications for post-partum nutrition and reproduction. Reprod. Domest. Anim. 43:31-39. https://doi.org/10.1111/j.1439-0531.2008.01140.x.

Lucy, M. C. 2011. Growth hormone regulation of follicular growth. Reprod. Fertil. Dev. 24:19-28. https://doi.org/10.1071/RD11903.

Meikle, A., M. Kulcsar, Y. Chilliard, H. Febel, C. Delavaud, D. Cavestany, and P. Chilibroste. 2004. Effects of parity and body condition at parturition on endocrine and reproductive parameters of the cow. Reproduction 127:727-737. https://doi.org/10.1530/ rep.1.00080.

Miettinen, H., and P. Huhtanen. 1996. Effects of the ratio of ruminal propionate to butyrate on milk yield and blood metabolites in dairy cows. J. Dairy Sci. 79:851-861. https://doi.org/10.3168/jds. S0022-0302(96)76434-2.

Rastani, R. R., R. R. Grummer, S. J. Bertics, A. Gümen, M. C. Wiltbank, D. G. Mashek, and M. C. Schwab. 2005. Reducing dry period length to simplify feeding transition cows: Milk production, energy balance, and metabolic profiles. J. Dairy Sci. 88:1004-1014. https://doi.org/10.3168/jds.S0022-0302(05)72768-5.

Reist, M., D. Erdin, D. von Euw, K. Tschuemperlin, H. Leuenberger, C. Delavaud, Y. Chilliard, H. M. Hammon, N. Kuenzi, and J. W. Blum. 2003. Concentrate feeding strategy in lactating dairy cows: Metabolic and endocrine changes with emphasis on leptin. J. Dairy Sci. 86:1690-1706. https://doi.org/10.3168/jds.S00220302(03)73755-2.

Roche, J. R., N. C. Friggens, J. K. Kay, M. W. Fisher, K. J. Stafford, and D. P. Berry. 2009. Invited review: Body condition score and its association with dairy cow productivity, health, and welfare. J. Dairy Sci. 92:5769-5801. https://doi.org/10.3168/jds.2009-2431.

Santschi, D. E., D. M. Lefebvre, R. I. Cue, C. L. Girard, and D Pellerin. 2011. Incidence of metabolic disorders and reproductive performance following a short (35-d) or conventional (60-d) dry period management in commercial Holstein herds. J. Dairy Sci. 94:3322-3330. https://doi.org/10.3168/jds.2010-3595. 
SAS Institute Inc. 2011. The SAS System for Windows. Release 9.3. SAS Institute, Cary, NC.

Schlamberger, G., S. Wiedemann, E. Viturro, H. H. D. Meyer, and M. Kaske. 2010. Effects of continuous milking during the dry period or once daily milking in the first 4 weeks of lactation on metabolism and productivity of dairy cows. J. Dairy Sci. 93:2471-2485. https://doi.org/10.3168/jds.2009-2823.

Steeneveld, W., A. T. M. van Knegsel, G. J. Remmelink, B. Kemp, J. C. M. Vernooij, and H. Hogeveen. 2014. Cow characteristics and their association with production performance with different dry period lengths. J. Dairy Sci. 97:4922-4931. https://doi. org/10.3168/jds.2013-7859.

Tamminga, S., W. M. Vanstraalen, A. P. J. Subnel, R. G. M. Meijer, A. Steg, C. J. G. Wever, and M. C. Blok. 1994. The Dutch protein evaluation system - The dve/oeb-system. Livest. Prod. Sci. 40:139-155. https://doi.org/10.1016/0301-6226(94)90043-4.

Van Es, A. J. H. 1975. Feed evaluation for dairy cows. Livest. Prod. Sci. 40:95-107. https://doi.org/10.1016/0301-6226(75)90029-9. van Knegsel, A. T. M., G. J. Remmelink, S. Jorjong, V. Fievez, and B. Kemp. 2014. Effect of dry period length and dietary energy source on energy balance, milk yield, and milk composition of dairy cows. J. Dairy Sci. 97:1499-1512. https://doi.org/10.3168/jds.2013-7391.

van Knegsel, A. T. M., S. G. A. van der Drift, J. Čermáková, and B. Kemp. 2013. Effects of shortening the dry period of dairy cows on milk production, energy balance, health, and fertility: A systematic review. Vet. J. 198:707-713. https://doi.org/10.1016/j. tvj1.2013.10.005.

Zbinden, R. S., M. Falk, A. Münger, F. Dohme-Meier, H. A. van Dorland, R. M. Bruckmaier, and J. J. Gross. 2016. Metabolic load in dairy cows kept in herbage-based feeding systems and suitability of potential markers for compromised well-being. J. Anim. Physiol. Anim. Nutr. (Berl). https://doi.org/10.1111/jpn.12498

Zom, R. L. G., G. André, and A. M. van Vuuren. 2012. Development of a model for the prediction of feed intake by dairy cows: 1. Prediction of feed intake. Livest. Sci. 143:43-57. https://doi. org/10.1016/j.livsci.2011.08.014. 